\title{
Is Kenya Facing East or West: An Empirical Analysis
}

\author{
X.N. Iraki $^{1}$ \\ ${ }^{1}$ University of Nairobi School of Business, Kenya \\ Correspondence: X.N. Iraki, University of Nairobi School of Business, Kenya. E-mail: xniraki@gmail.com
}

Received: October 11, 2018

Accepted: November 30, 2018 Online Published: December 3, 2018

doi:10.5539/ibr.v11n12p134

URL: https://doi.org/10.5539/ibr.v11n12p134

\begin{abstract}
In the last two decades China's economic influence in Africa has increased espoused by huge investment in infrastructure like roads, railways, airports and seaports. This has led many scholars to suggest that Africa is facing East away from the traditional West. The Western influence had permeated into governance, education religion and even consumption. Of interest is if China has successfully displaced the west from Africa in such a short time. This study investigates if Africa, in particular Kenya has really faced East (read China). We expect economies near each other geographically or are culturally close because of history e.g. colonialism to have highly correlated GDP growths. This is supported by gravity theory of trade. In this paper, GDP growth rates of Kenya and a selected number of countries from the West and East are correlated for a 50 years period. Analysis is then broken into decades to see the change in patterns. Analysis of correlations during the different Kenyan presidencies then before and after the cold war is carried out. All the data in this paper is sourced from World Development Indicators, a World Bank Data base. The hype about facing East for Kenya is not supported by data. Kenya in the last 20 years has looked East, but did not abandon the West. This dualism may change with Brexit, Trump in White House and envisaged Africa's free trade area.
\end{abstract}

Keywords: Kenyatta, China, Kenya, Brexit, Africa Free Trade Area

\section{Introduction}

In the 1970s up to 1980s, the following brands were common in Kenya; Bedford, Anglia, Leyland, Rover and ICL. Made in England was common from home appliances to cars on the road. It was not just in products; schooling in England was prestigious with two of Kenya's four presidents schooling there, Jomo Kenyatta and Mwai Kibaki. Both went to London School of Economics.

In the 1970s and 1980s, being seen around Chinese Embassy would have earned you a jail term in a Kenyan prison after being labelled a communist sympathizer. In the early 1990s perhaps because of economic liberalization and end of cold war, brands from East started appearing in Kenya. They include Faw, KIA, Daewoo, Samsung, Toyota (which had come much earlier, with the first car sold in Kenya 1965), Tata, Haier, Huawei and Tecno. Chinese products became popular while Chinese road contractors replaced well known western firms like Put Sarajevo, Strabag and Mowlem. Now we got Wu Yi, China Road and Bridge Company, Sinohydro and others. The size of Chinese contracts and their frequency raised eyebrows in media and on the streets.

Interestingly, other Easterners like Japanese, Indians, and Koreans never raised much concern at the Chinese arrival in Kenya. Indians had been in Kenya for over 100 years after coming to help Britons build the railway line (Methu, 2014). Rarely discussed is that Indians helped Britain defeat Germany in World War (Willson, 2014). Koreans came through trade mostly in motor industry (Hyundai, KIA, and Sangyong) and electronics (Samsung and LG). They also came through some religious congregations such as Good News Mission Church (Zirulnick, 2014). Koreans mostly followed the Japanese model of focusing on trade.

Chinese have gone beyond trade to cultural influence including setting up Confucius institutes to teach Mandarin in Kenyan Universities. A number of Kenyans have got scholarships to study in China too (Embassy of China in Kenya, 2018). Lately, Kenyans have been going to India for medical treatment (Musyoka, 2012). They had flocked there earlier for higher education when opportunities of the same were limited in Kenya. Lots of pharmaceutical products sold in Kenya are from India.

Since President Kibaki's leadership from 2002-2012, there has been an impression that Kenya is facing east, meaning China. The fear of the dragon, as China is often referred to, appears real (The Economist, Aug 13, 
2016). This paper investigates if economically Kenya has shifted to the East. Politically and culturally, Kenya is still very Western with regular polls, English as the official language and children getting very western names like Charlotte, Brian, Catherine and Jayden.

The analysis builds on the work of Baxter \& Kouparitsas (2005). They suggest that trade depends on distance, the greater the distance between two countries, the higher are the costs associated with transporting goods, thereby reducing the gains from trade and reducing trade itself. This is supported by (Glick and Rose, 2002). In addition, common border and common language enhances trade between countries. Colonial ties are an important driver of international trade. The paper also borrows from the gravity model, originally from Jan Tinbergen in 1962 shown here.

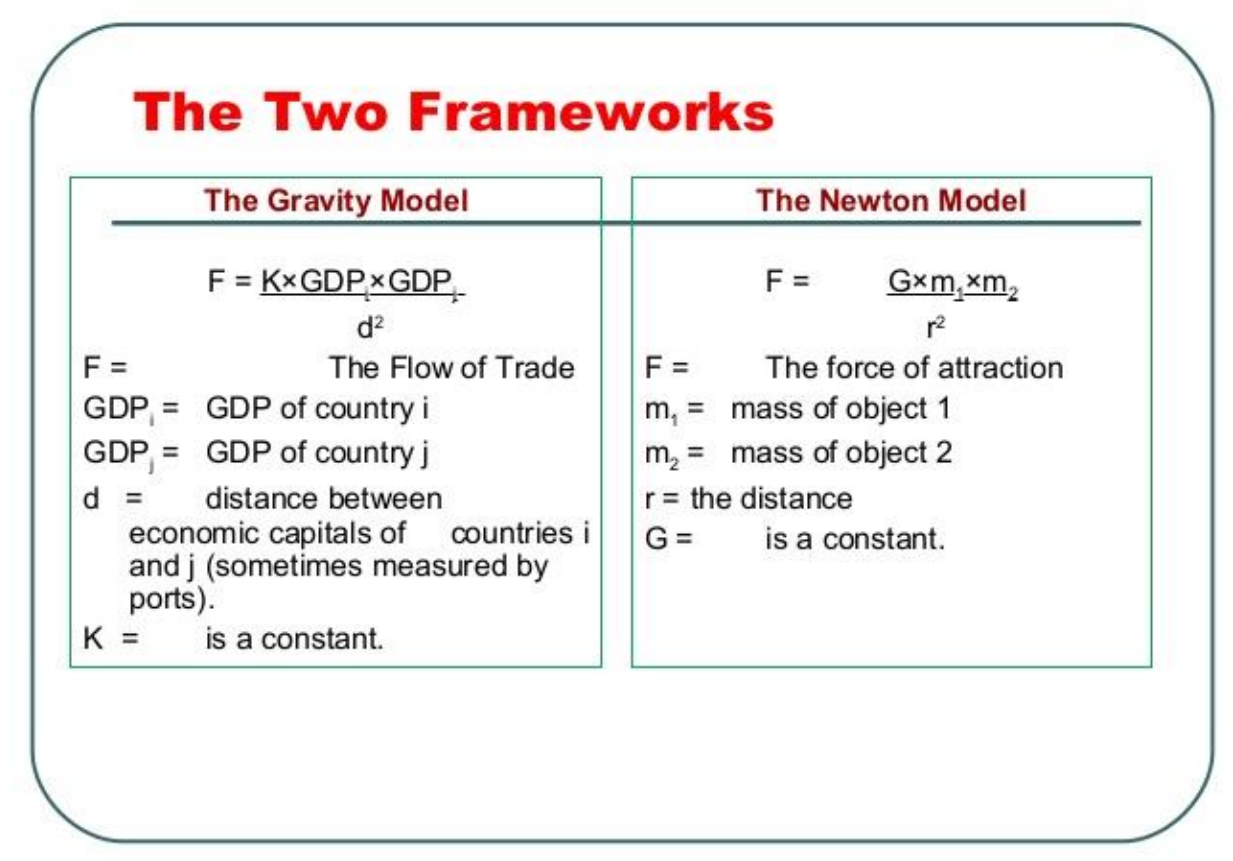

Figure 1. Gravity Model

\section{Methodology}

We expect economies are near each other or are culturally close because of history e.g. colonialism to have highly correlated growths. In this paper, GDP growth rates of Kenya and a selected number of countries from the West and East are correlated for a 50 years period. Analysis is then broken into decades to see the change in patterns. Analysis of correlations during the different presidencies and before and after the cold war is carried out. In Kenya, end of cold war coincided with advent of multiparty politics.

The choice period after 1963 is informed by Kenya's independence and control over her political and economic policies. All the data in this paper is sourced from World Development Indicators, a World Bank Data base.

The choice of countries was based on a number of factors. One, UK was Kenya's colonial power from 1895 to 1963. Germany is the leading Economic power within EU while USA is the world's biggest economy. India, China and Japan are the leading economic powers in the East and would act as counterweight to the big Western nations. The choice of Tanzania (TZ) and Uganda is based on neighborliness while South Africa is chosen because it's Africa leading economic power. Other factors such as diplomacy, students exchange and treaties are factored in GDP growth. Negative correlation means the two countries are "facing" away from each other while positive correlation means the countries are facing each other.

\section{Results}

Data is first analyzed for the whole period then broken into decades, presidencies and pre and post-cold war period. The correlations are calculated and graphed. 


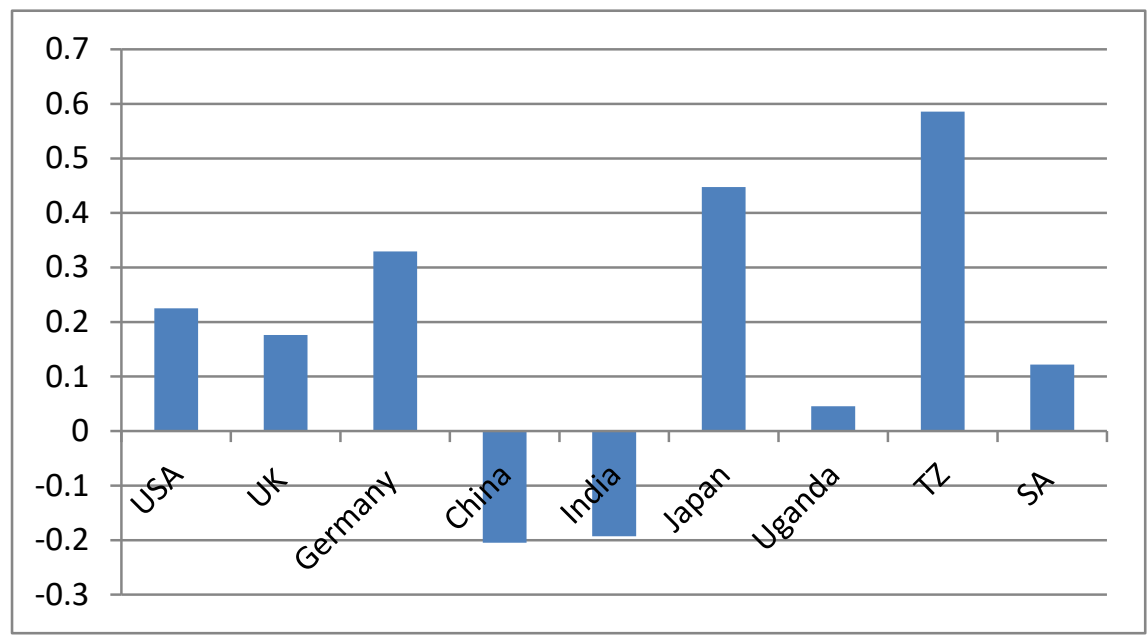

Figure 2. Growth Correlations for whole period: 1964-2013

The data for the 50-year period indicates that Kenya's economy was closest to USA, UK, Germany, TZ and Japan. The low correlation for Uganda might be attributed to political instability up to 1986. High Tanzania (TZ) correlation is the fruit of East African Community. UK ties are colonial. USA tie is historical with the famous airlift of 1959 when Kenya's future leaders went to study in USA (Mutu, 2016). That group included President Obama's father who was not in the original airlift. For Germany, it surprising because the cultures of the two countries are very different. However, Germany was the first country to recognize independent Kenya and its diplomatic cars have the number plate 1CD. Germany has also been cultivating close ties with Kenya: German is taught in a number of Kenyan schools and through, DAAD, cultural exchange programs and scholarships for Kenyan students have been availed. Cleary, Kenya never faced East on average for the 50 years, despite "gravity" effects i.e., the big populations of India and China.

Table 1. Correlation between Kenya's GDP growth and Growth of selected countries; Decade by Decade

\begin{tabular}{lrrrrrrrrr}
\hline Period & \multicolumn{1}{l}{ USA } & \multicolumn{1}{l}{ UK } & Germany & \multicolumn{1}{l}{ China } & \multicolumn{1}{l}{ India } & \multicolumn{1}{l}{ Japan } & \multicolumn{1}{l}{ Uganda } & \multicolumn{1}{c}{ TZ } & \multicolumn{1}{c}{ SA } \\
\hline $1964-2013$ & 0.2250 & 0.1763 & 0.3295 & -0.2046 & -0.1927 & 0.4476 & 0.0456 & 0.5859 & 0.1221 \\
$1964-1973$ & 0.1048 & -0.1705 & -0.9002 & -0.3126 & -0.4032 & 0.2454 & No data & No data & -0.5927 \\
$1974-1983$ & 0.3528 & 0.2019 & 0.5489 & 0.1558 & -0.2418 & 0.3532 & No data & No data & 0.2538 \\
$1984-1993$ & 0.1779 & 0.6509 & 0.2369 & -0.4412 & 0.3827 & 0.6431 & -0.1048 & 0.8532 & 0.2837 \\
$1994-2003$ & -0.2453 & -0.2752 & -0.0999 & 0.2310 & 0.6661 & -0.0235 & 0.4566 & -0.1694 & -0.1872 \\
$2004-2013$ & 0.6033 & 0.5969 & 0.5458 & 0.3964 & 0.7704 & 0.6537 & -0.1239 & 0.3756 & 0.3865 \\
\hline
\end{tabular}

Note. Germany data starts from 1971, Tanzania from 1989, Uganda in 1983.

\subsection{Graphical Analysis Decade by Decade}

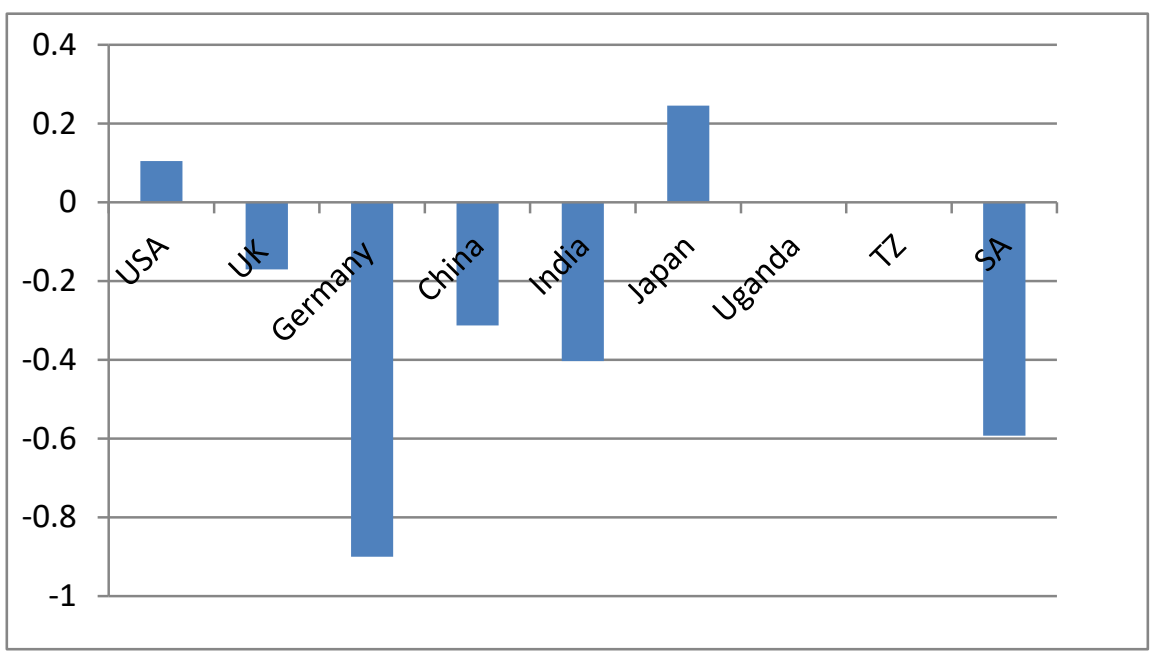

Figure 3. First decade 1964-1973 
The negative correlation with Germany in the first decade after independence (uhuru) is because data is available from 1971. It may not reflect the true state of relationship among the two nations. In the first decade of independence, only USA and Japan stand out. East (India and China) were not in our economic lexicon yet. Airlift in 1959 prepared USA for economic ties with Kenya. Japan started selling cars in Kenya in 1965. For TZ and Uganda, no data is available. The negative correlation with South Africa (SA) was because of political isolation despite the presence of Afrikaner farmers in Kenya before independence. Most Afrikaans or Boers left for South Africa before Kenya's independence. List of voters in pre-colonial Kenya has lots of Afrikaners like Kruger, Van Straaten, Van Dyk, Van Blerk, Coetzee and others (Kenya Gazette, 1938). A cemetery and a church at Nyahururu, a town $200 \mathrm{~km}$ North West of Nairobi is a silent reminder that Afrikaans once farmed there. The negative correlation for Kenya with UK in the first decade is surprising. It could be as result of political upheavals in Kenya that impacted economic growth negatively.

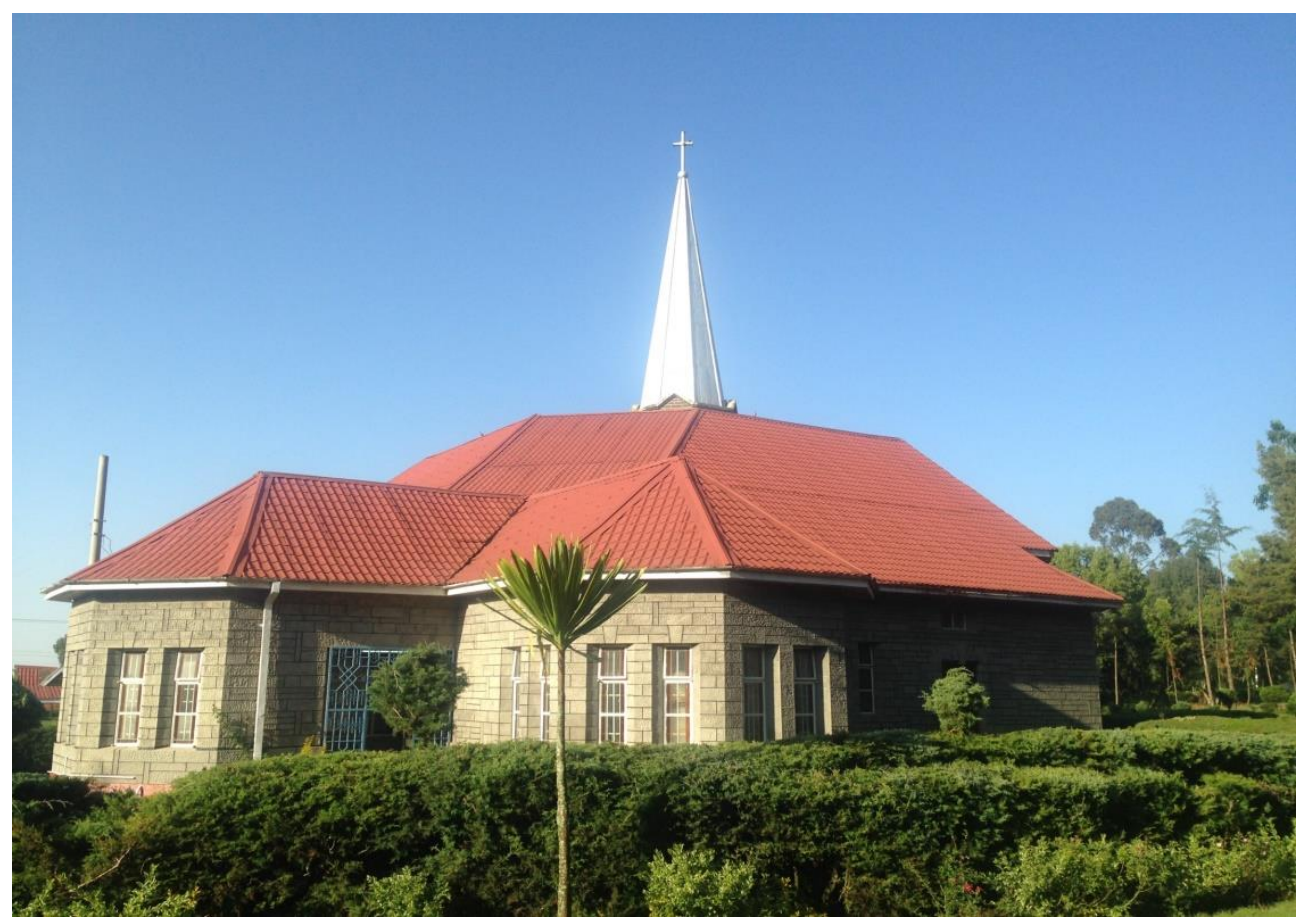

Figure 4. Photo of An Afrikaans Church in Nyahururu, Kenya build in 1952. Photo by Author

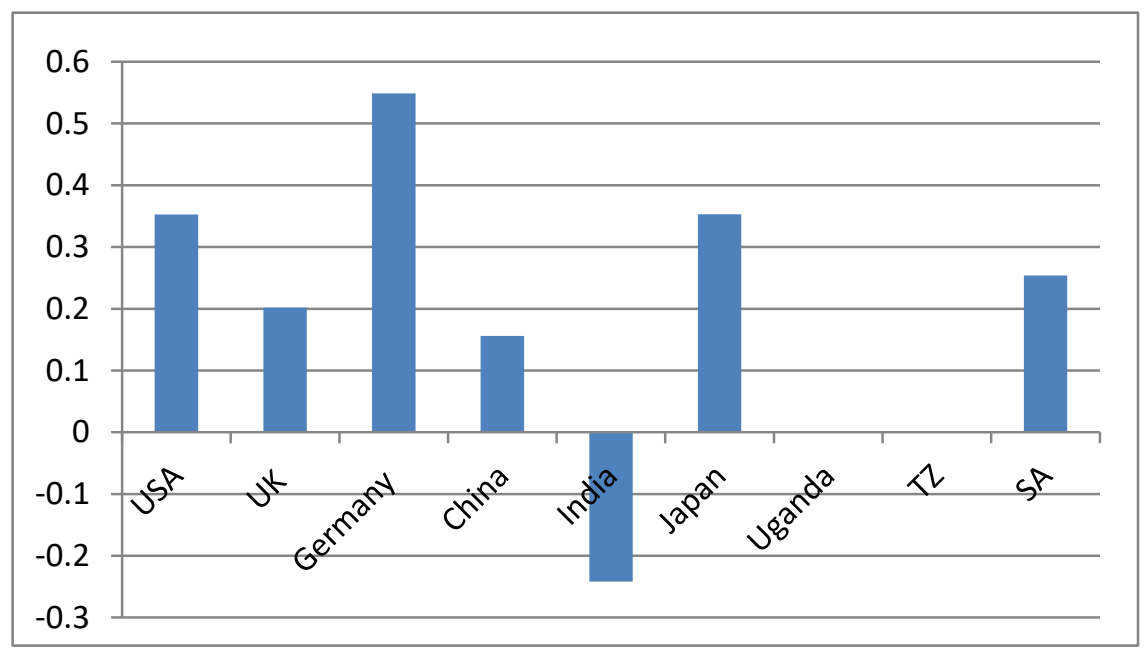

Figure 5. Second Decade (1974-1983) 
The second decade can be called the "decade of consolidation". The correlations went up, except for India. Uganda and TZ have no data. SA is positive. Did Kenya start busting sanctions and trade with South Africa? China correlation is positive. Sanghi and Johnson (2016) observe that China despite the popular misconceptions has benefits to Africa e.g. consumers now have greater variety and choice, create jobs. They conclude, "If Kenya leverages Chinese know-how and uses relatively cheap imports to satisfy the basic needs of the population, it could at the same time jump start its export engine in areas of comparative advantage such as tea, cut flowers, or chemicals." China greater engagement could have resulted from opening up in 1978 under Chairman Deng Xiaoping (Vogel, 2011).

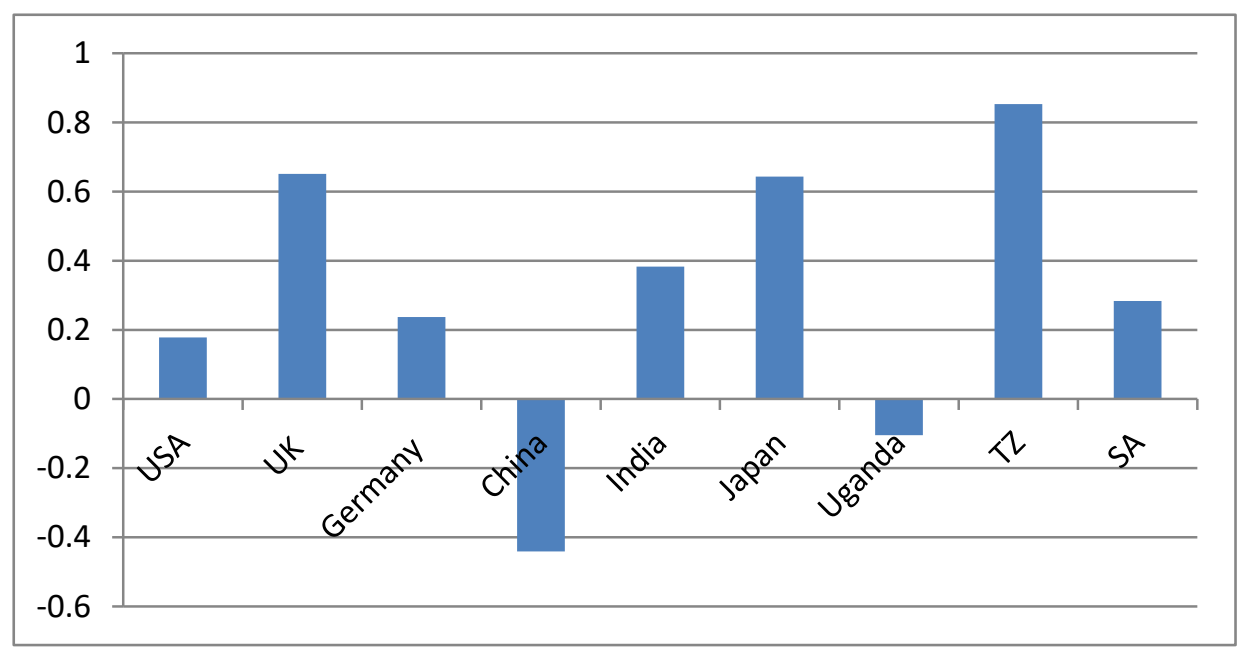

Figure 6. Third Decade (1984-1993)

The negative correlation with China in the third decade is because of her fast growth as Kenya declined, see figure 7. India started shining. Uganda still lacked data. UK, Japan and Tanzania stand out. UK for colonial ties, Tanzania for neighbourliness and India for close proximity and historical ties. We would have expected India to be highly correlated with Kenya because of proximity and history. India is a democracy and talks English like Kenya; both were British colonies. During this decade, East was about Japan and India. China was missing (see high negative correlation).

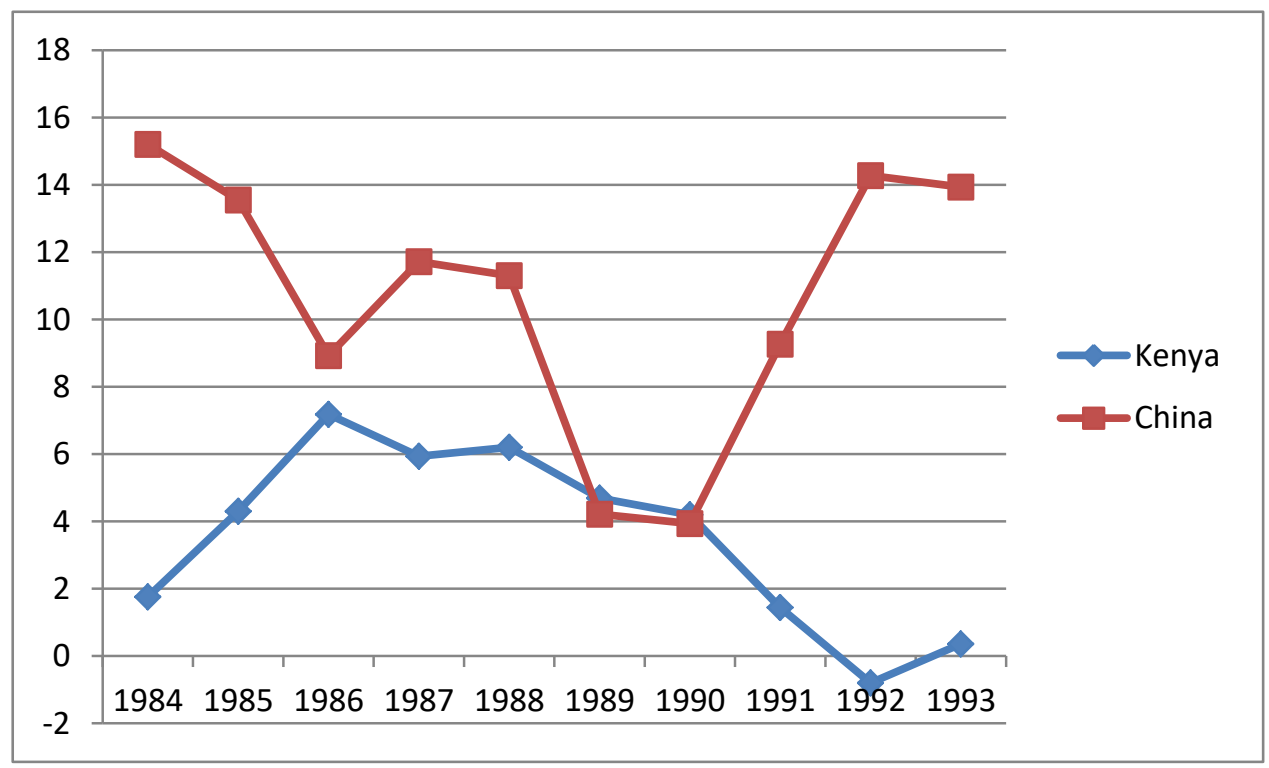

Figure 7. Growth rates between Kenya and China (1984-1993) 


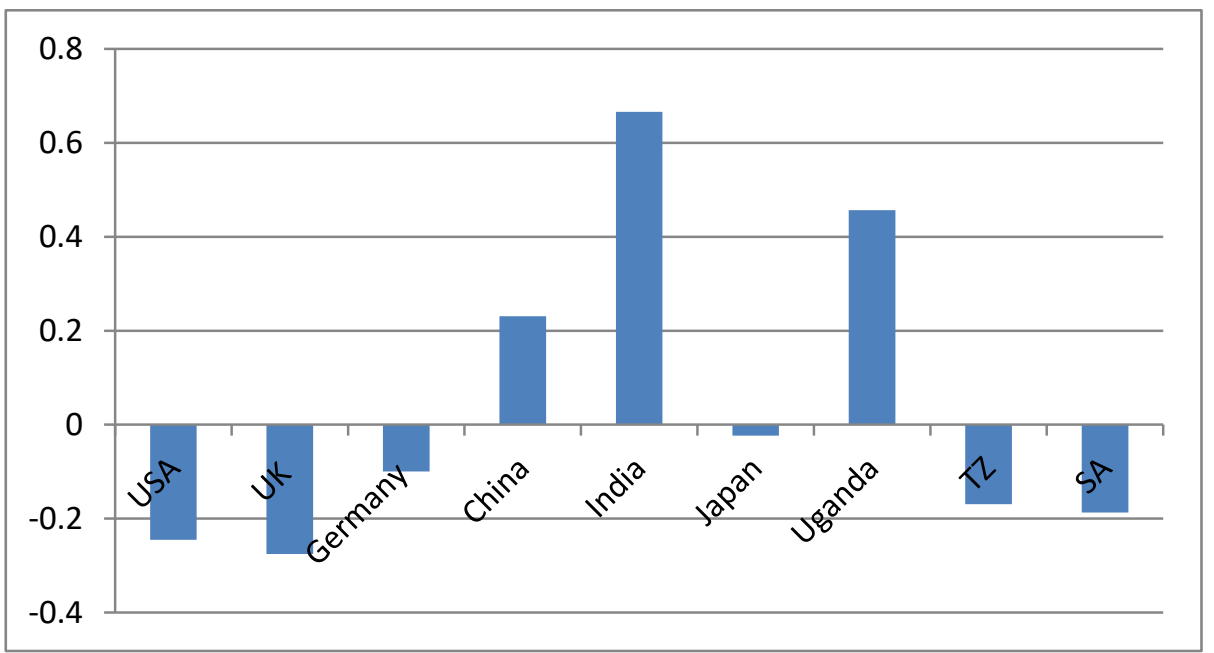

Figure 8. Fourth Decade (1994-2003)

The negative correlation with western countries like USA, Germany and UK might reflect the bad relations with western donors including aid freeze and political instability resulting in political violence. This data reflects decline in Kenya's economy. The real turning to the East started in this decade. We note the high correlation with India and China while it is negative for Western powers and South Africa. While most Kenyans think turning east started with President Kibaki, it had stated earlier during President Moi era. The Japanese engagement with Kenya declined in this decade perhaps as reflection of Japan's lost decade and Asian crisis captured by figure 6 . Pape(1996) notes "The early 1990s marked the worst time in Kenyan history, in economic development terms. This poor performance was due to drought, structural rigidities, lack of monetary discipline, non-enforcement of banking regulations, and reduced donor assistance. Against this background, the Government went for a comprehensive, IMF-supported structural adjustment programme."

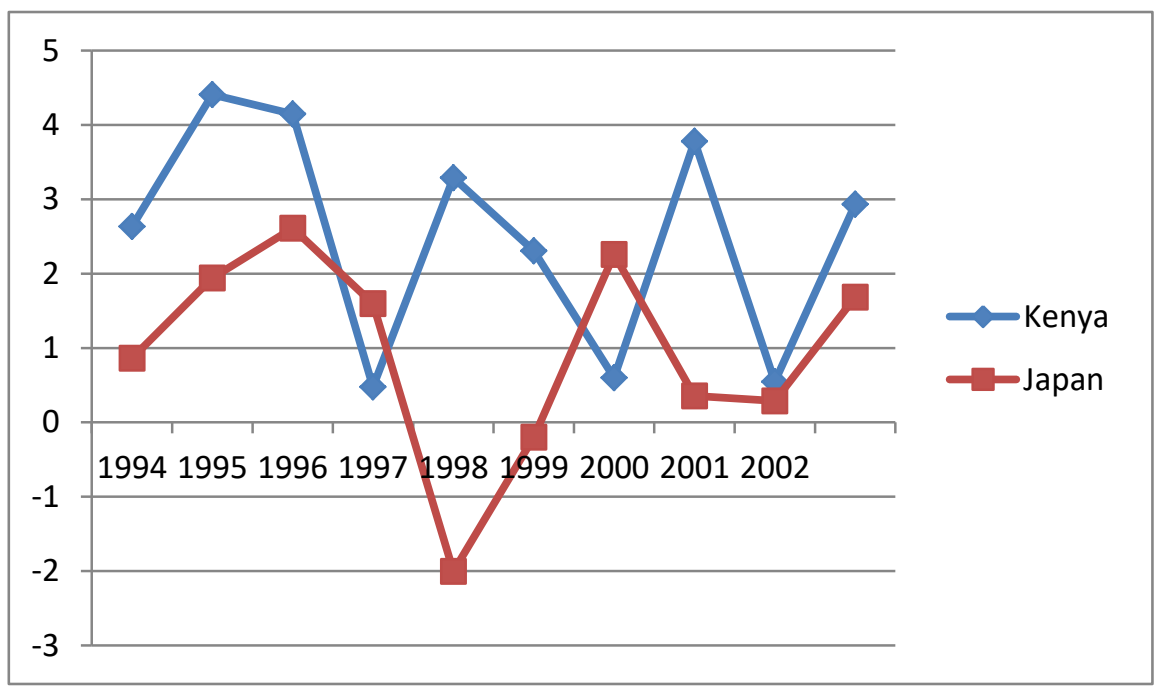

Figure 9. Asian Crisis: Growth in Japan vs. Kenya 


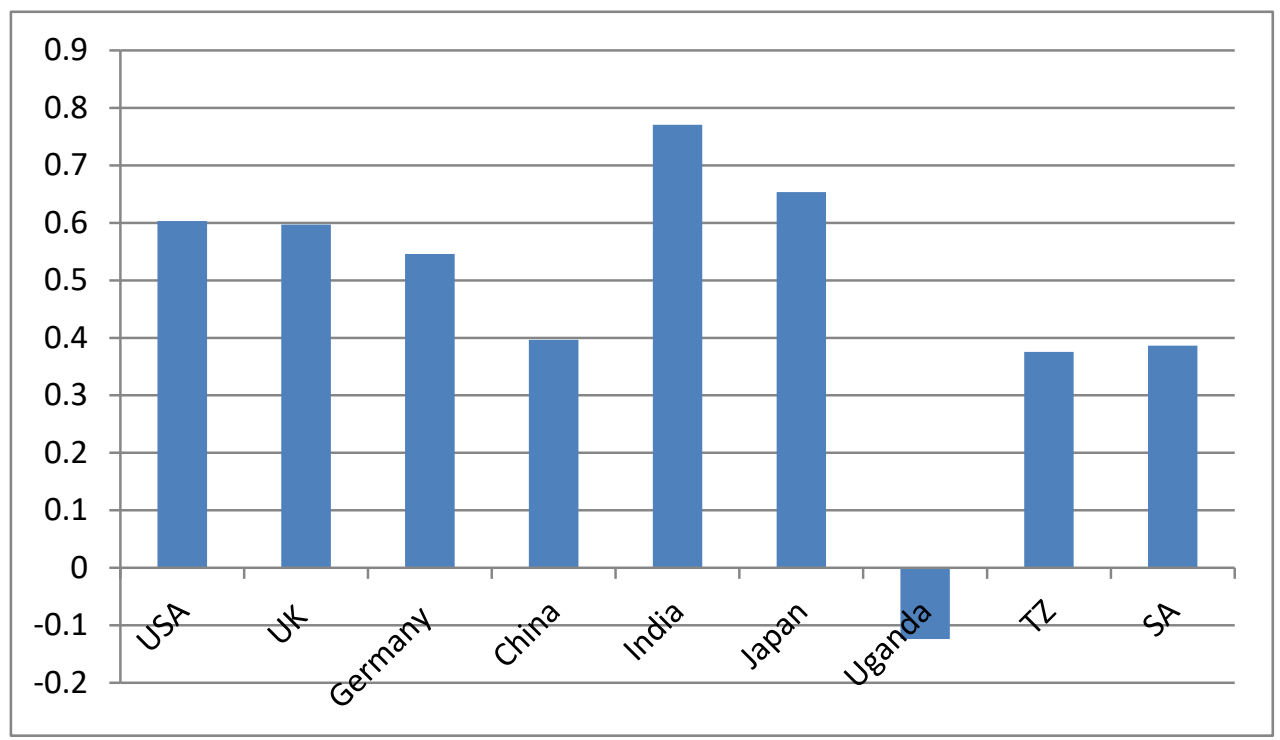

Figure 10. Fifth Decade: 2004-2013

The last decade shows that Kenya faced everywhere, not just East. India and Japan are ahead of China. Sanghi and Johnson (2016) are right in suggesting that the fear of China is a myth, at least from the Kenyan perspective. Brexit might cement the ties with UK further going by the recent visit (2018) to Kenya by British Prime Minister. President Uhuru invitation to USA in 2018 and visit to China there after shows that Kenya is now facing everywhere not just East or West. It is not clear why Kenya and Uganda are not growing in tandem despite close neighbourliness. The section investigates how different regimes in the 50 years have faced east or west.

Table 2. Correlations in GDP growth and presidencies

\begin{tabular}{|c|c|c|c|c|c|c|c|c|c|}
\hline & USA & UK & Germany & China & India & Japan & Uganda & $\mathrm{TZ}$ & SA \\
\hline Jomo & 0.2447 & 0.1493 & 0.3358 & -0.1720 & -0.3440 & 0.3426 & No data & No data & -0.2880 \\
\hline Moi & 0.0139 & 0.1866 & 0.3187 & -0.3124 & -0.0811 & 0.5122 & -0.0679 & 0.3792 & 0.2809 \\
\hline Kibaki & 0.5057 & 0.4467 & 0.5883 & 0.4804 & 0.7550 & 0.5844 & -0.0470 & 0.3325 & 0.4081 \\
\hline Uhuru & -0.5985 & -0.9923 & -0.5478 & 0.1465 & -0.2795 & 0.8432 & -0.4950 & 0.6006 & 0.3478 \\
\hline
\end{tabular}

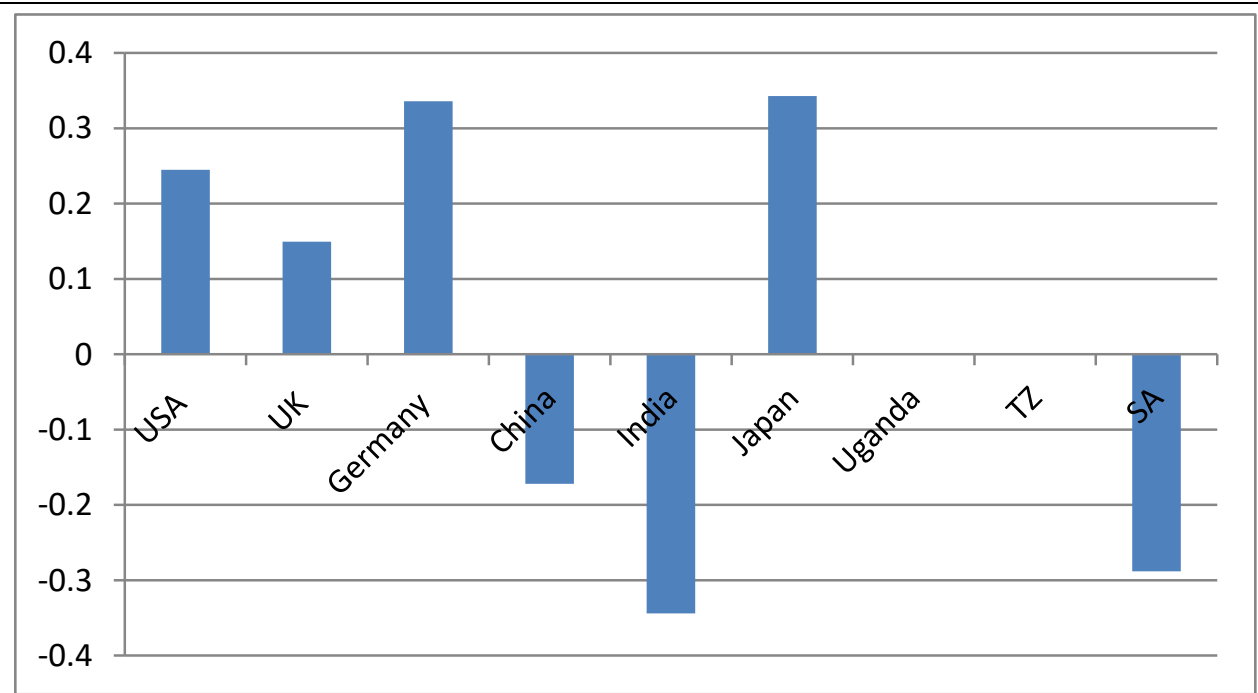

Figure 11. Presidencies: Jomo Kenyatta (1964-1978)

Jomo Kenyatta never faced East (excluding Japan). Jomo faced West most of his political life. South Africa was still a no-go option. Does this reflect the fact that he lived in UK for over 15 years, specifically in UK and even schooled there at London School of Economics? 


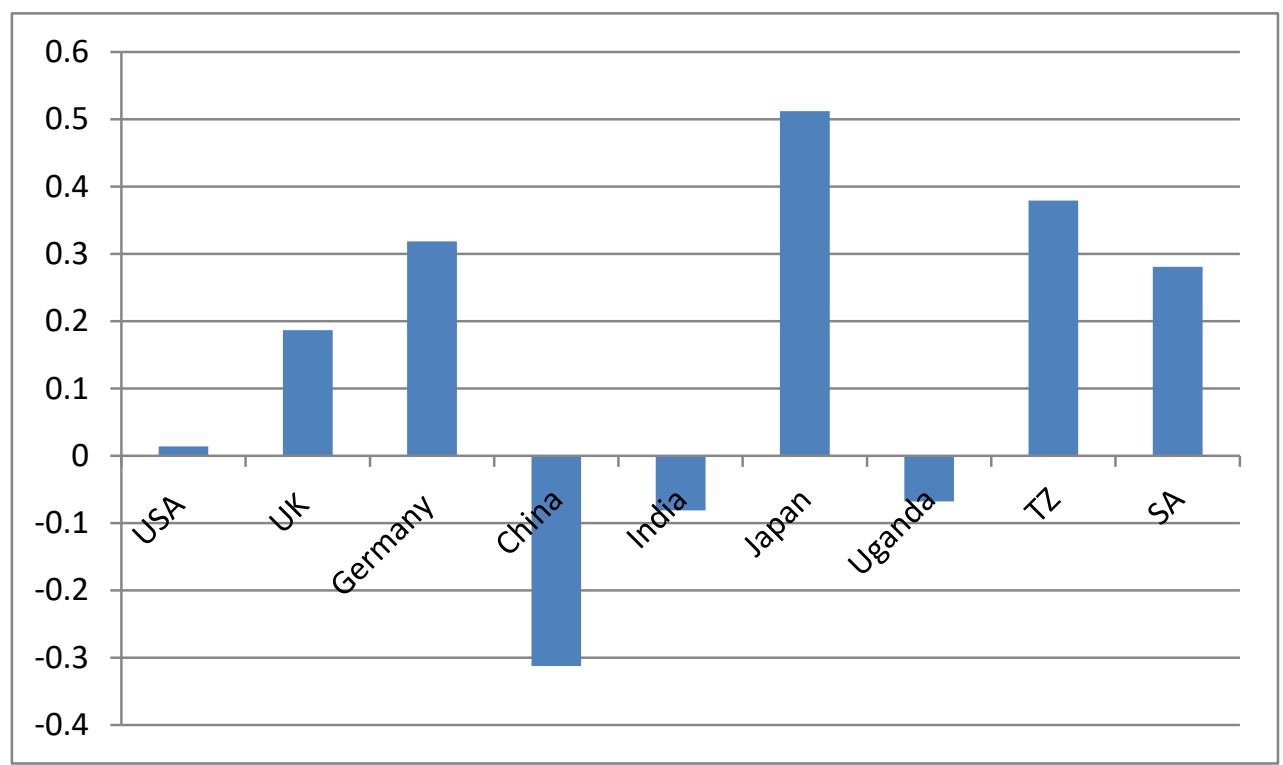

Figure 12. Daniel Arap Moi (1979-2002)

Moi like Jomo Kenyatta never faced East, except Japan. The low correlation with USA can be attributed to financial crisis in the USA in 1980-81, political violence in Kenya in 1997 and agitation for political pluralism(multipartism) in 1991. See figure 13.

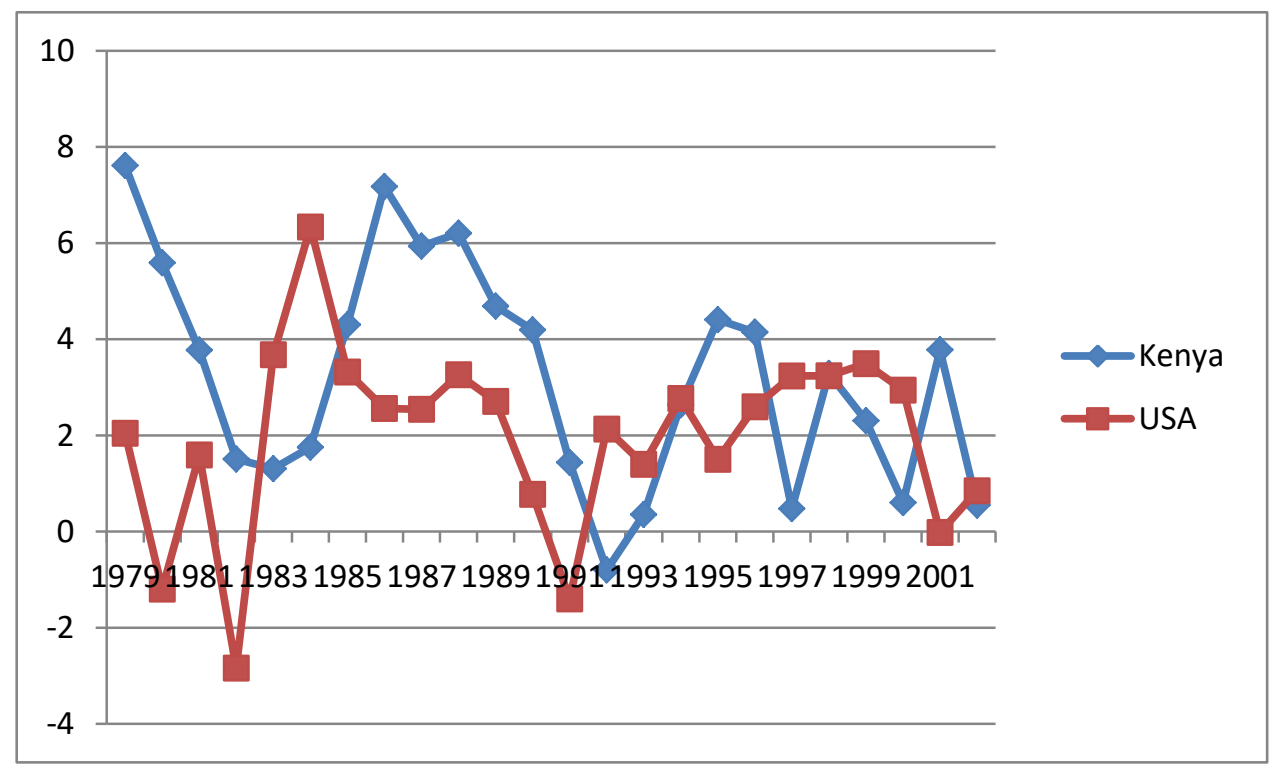

Figure 13. Kenya vs. USA Growth rates (1979-2002) 


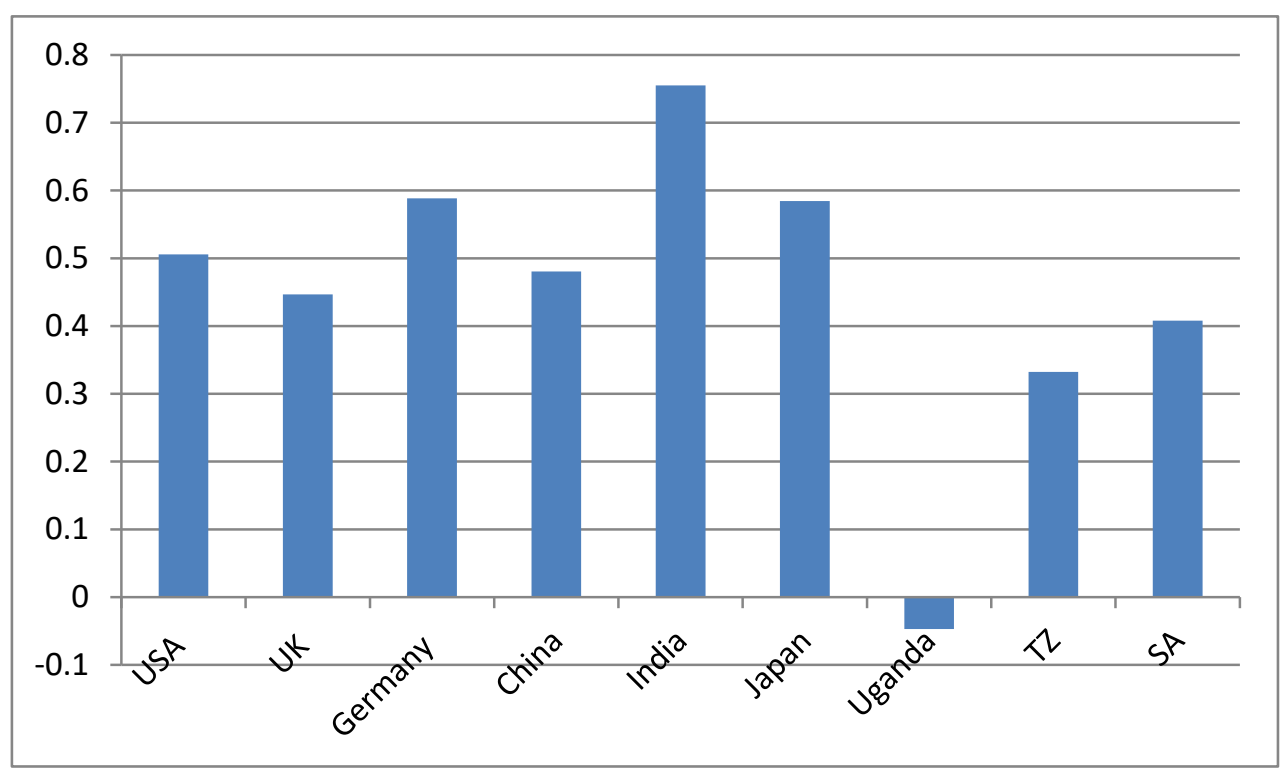

Figure 14. Mwai Kibaki (2002-2013)

Kenya started looking in all directions during Kibaki era; East, West, North and South. India got closer than even China and Japan. Uganda got out of tandem. This graph shows clearly that the claim that Kibaki faced East is a myth, he faced everywhere.

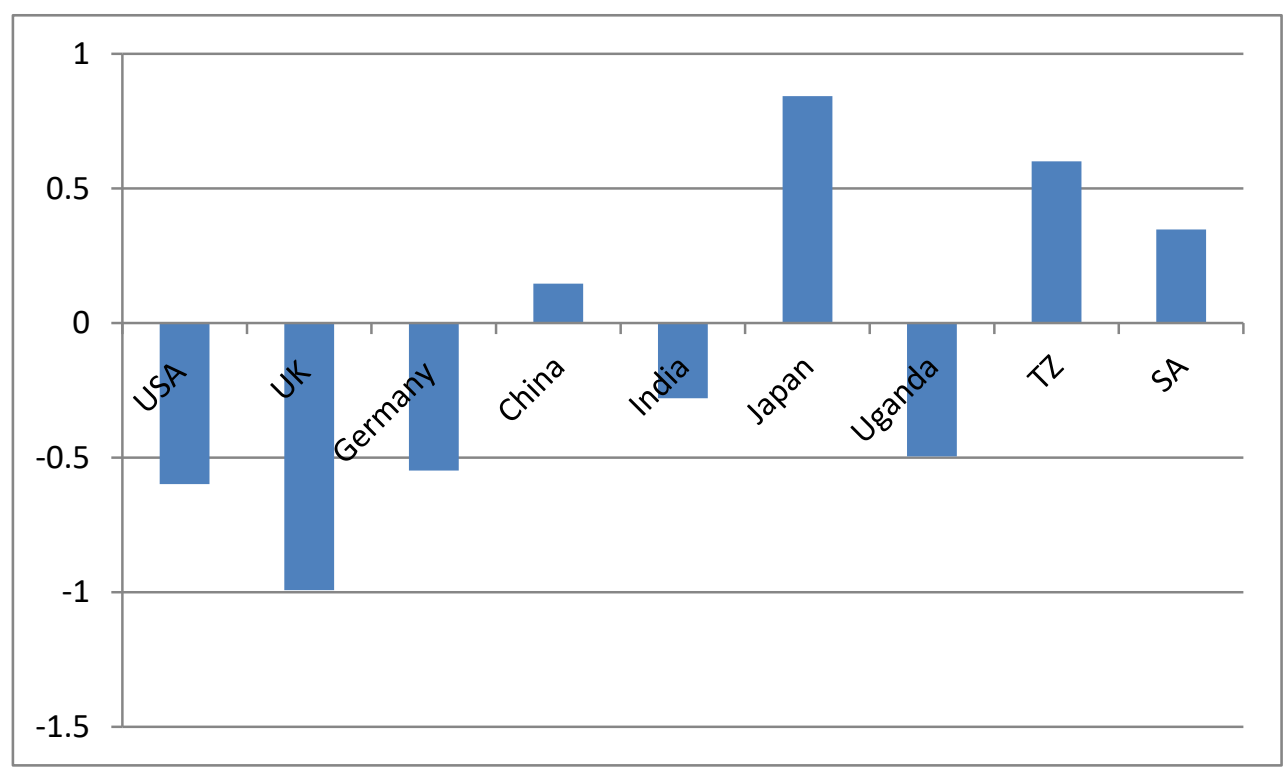

Figure 15. Uhuru Kenyatta presidency (2013 to Present)

The sample here is too small to make any credible conclusion. Using the few data points, Uhuru has looked East, away from West. Is it the International Criminal Court (ICC) effect? Looking at Standard Gauge Rail (SGR) build by Chinese, new container terminal at Mombasa built by Japanese and the number of Kenyans going to India for medical services, we can cautiously conclude we are facing East. The next section looks at the effect of cold war on Kenya economic orientation.

\subsection{Cold War and Kenya's Economic Direction}

Subtracting correlations after cold war from that before cold war shows that Kenya faced east more after cold war; all western powers show reduction in correlation after cold war and so did Japan. South Africa perhaps because of her independence in 1994 seems to have attracted a lot of Kenyan attention. 
Table 3. Kenya and Cold War

\begin{tabular}{lcrrrrrrrr}
\hline Kenya GDP growth correlation with & USA & \multicolumn{1}{c}{ UK } & Germany & China & India & Japan & Uganda & TZ & SA \\
\hline 1964-1990(before Cold War) & 0.204 & 0.146 & 0.349 & -0.190 & -0.320 & 0.382 & 0.082 & -1.00 & -0.030 \\
1991-2015(after Cold war) & $\underline{0.029}$ & $\underline{0.133}$ & $\underline{0.203}$ & $\underline{-0.070}$ & $\underline{0.736}$ & $\underline{0.249}$ & $\underline{0.1384}$ & $\underline{0.627}$ & $\underline{0.4194}$ \\
Correlation after cold war -before cold war) & -0.175 & -0.0130 & -0.146 & 0.121 & 1.056 & -0.133 & 0.057 & 1.627 & 0.449 \\
\hline
\end{tabular}

\section{Conclusion}

The hype about Kenya facing East economically is not supported by data. Kenya in the last 20 years has looked East but has not abandoned the West. The gravity model can explain this dualism. History and language ties Kenya to the West. She was a British colony and English is the official language. Large populations and economies of China, Japan and India are attractive to Kenya as markets. This dualism may change with time as Brexit and Trump in White House starts to take effect. Africa's free trade area might also change the economic orientation of Kenya as the Nigerian president puts it, "We must push ahead to speedily establish the Continental Free Trade Area (CFTA), which will make Africa more integrated, united and prosperous." An interesting observation in Kenya is that county governments are buying USA made cars like Chevrolet and Ford while national government is buying Chinese cars like Grand Tiger and Cherry. While China build standard gauge rail (SGR), Pizza Hut, Subway, KFC, Burger King and other Western (read USA) brands are opening up in Nairobi. Data suggests Kenya will continue facing both directions.

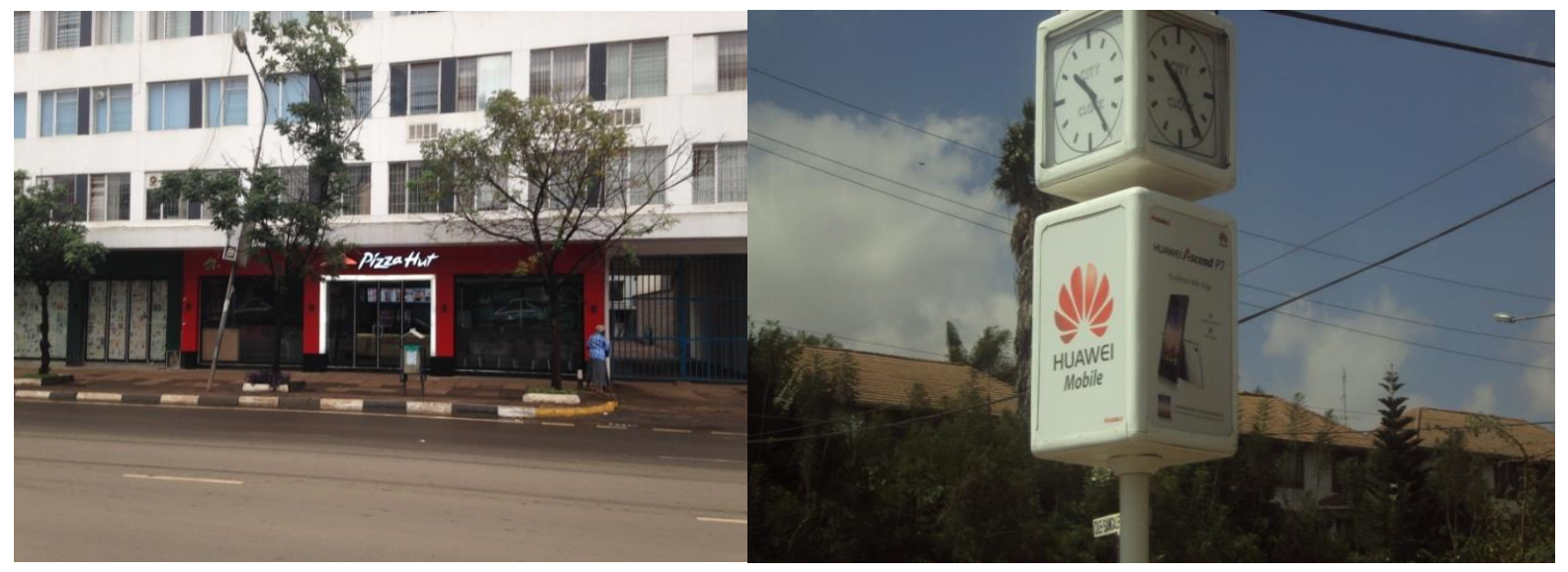

Figure 16. Facing West and East at the same time in Nairobi, Kenya. Photo by author

\section{Suggestions for Further Research}

Further research on economic orientation of other African countries is necessary. Data analysis can shed some light on whether Francophone, Lusophone and Spanish speaking countries are still economically "facing" towards their former colonial powers. Of greater interest is countries like Ethiopia and Liberia that were never colonized. Simulation can be used to pick data from more samples and see dynamic economic orientation over time.

\section{References}

Akorede, S. (2018). How a single market would transform Africa's economy. World Economic Forum.

Battersby, B., \& Ewing, R (2005). International trade performance: the gravity of Australia's remoteness, Treasury Working Paper.

Chaney, T. (2013). The Gravity Equation in International Trade: An Explanation. NBER Working Paper No. 19285.

Embassy of China. (2018). Chinese Government Scholarships 2008/2009. http://ke.china-embassy.org/eng/old/zt/cs/Scholarship/

Flach, L., \& Unger, F. (2016). Quality and Gravity in International Trade, CESifo Conference on Global Economics, 13-14 May, 2016.

Glick, R., \& Rose, A. K. (2002). Does a currency union affect trade? The time-series evidence. European Economic Review, Elsevier, 46(6), 1125-1151, June. https://doi.org/10.1016/S0014-2921(01)00202-1

Kenya, G. (1938). The Official Gazette of the Protectorate and Colony of Kenya, March 7, 1938, XL(13), Nairobi, Kenya. 
Kouparitsas, M., \& Baxter, M. (2006). What Determines Bilateral Trade Flows? Boston University and NBER Federal Reserve Bank of Chicago.

Magnus, M., Lipsey, R., \& Ohlsson, L. (1989). What Do Rich Countries Trade with Each Other? R\&D and the Composition of U.S. and Swedish Trade, NBER Working Paper No. 3140 (Also Reprint No. r1551)

Methu, S. (2014). The Indian migrants who built Kenya's 'lunatic line', CNN http://edition.cnn.com/2014/12/11/world/africa/kenya-railways-india/index.html

Musyoka, C. (2012). Why Kenyans Prefer Indian Medical Treatment, Daily Nation, August 13, 2012.

Mutu, K. (2016). East Airlifts of US: The first Kenyans to study in America. The EastAfrican, December 3.

Noguera, G. (2012). Trade Costs and Gravity for Gross and Value-Added Trade, Job Market Paper.

Pape, E. (1996). Kenya's Economy in the 1990s, The Courier - №159 - Sept- Oct 1996, UNESCO.

Sanghi, A., \& Johnson, D. (2016). Three myths about China in Kenya, The Brookings Institution. The Economist, Asia's scramble for Africa; India, China and Japan are battling for influence Aug $13^{\text {th }} 2016$.

Tinbergen, J., \&Bos, C. (1962). Mathematical Models for Economic Growth,. New York: McGraw-Hill Publishing Co., 1962. viii, 136.

Vogel, E. (2011). China under Deng Xiaoping's leadership, East Asia Forum, 27 September.

Wall, H. (2000). Gravity Model Specification and the Effects of the Canada-U.S. Border, Working Paper 2000-024A, Federal Reserve Bank of St. Louis.

Willson, J. G. (2014). Guerrillas of Tsavo, James Willson, Diani, Kenya.

Zirulnick, A. (2014). Why are Korean missionaries flocking to Kenya? http://www.csmonitor.com/World/Africa/2014/1116/Why-are-Korean-missionaries-flocking-to-Kenya

\section{Copyrights}

Copyright for this article is retained by the author(s), with first publication rights granted to the journal.

This is an open-access article distributed under the terms and conditions of the Creative Commons Attribution license (http://creativecommons.org/licenses/by/4.0/). 